http://dx.doi.org/10.11646/zootaxa.3765.3.2

http://zoobank.org/urn:lsid:zoobank.org:pub:62224480-B209-4D05-90F4-0739FBC44F3B

\title{
Potamotrygon limai, sp. nov., a new species of freshwater stingray from the upper Madeira River system, Amazon basin (Chondrichthyes: Potamotrygonidae)
}

\author{
JOÃO PEDRO FONTENELLE ${ }^{1}$, JOÃO PAULO C. B. DA SILVA \& MARCELO R. DE CARVALHO \\ Departamento de Zoologia, Instituto de Biociências, Universidade de São Paulo, Rua do Matão, Travessa 14, no. 101, CEP 05508- \\ 090, São Paulo, SP, Brazil.E-mails: jpfontenelle@ib.usp.br (JPF); jpcbs@ib.usp.br (JPCBS); mrcarvalho@ib.usp.br (MRC) \\ ${ }^{1}$ Corresponding author
}

\begin{abstract}
Potamotrygon limai, sp. nov., is described from the Jamari River, upper Madeira River system (Amazon basin), state of Rondônia, Brazil. This new species differs from congeners by presenting unique polygonal or concentric patterns formed by small whitish spots better defined over the posterior disc and tail-base regions. Potamotrygon limai, sp. nov., can be further distinguished from congeners in the same basin by other characters in combination, such as two to three rows of midtail spines converging to a single irregular row at level of caudal sting origin, proportions of head, tail and disc, patterns of dermal denticles on rostral, cranial and tail regions, among other features discussed herein. Potamotrygon limai, sp. nov., is most similar to, and occurs sympatrically with, $P$. scobina, and is distinguished from it by lacking ocellated spots on disc, by its characteristic polygonal pattern on posterior disc, a comparatively much shorter and broader tail, greater intensity of denticles on disc, more midtail spine rows at tail-base, and other features including size at maturity and meristic characters. Potamotrygon limai, sp. nov., is also distinguished from other species of Potamotrygon occurring in the Amazon region, except $P$. scobina, by presenting three angular cartilages (vs. two or one). This new species was discovered during a detailed taxonomic and morphological revision of the closely related species $P$. scobina, and highlights the necessity for thorough and all-embracing taxonomic studies, particularly in groups with pronounced endemism and morphological variability.
\end{abstract}

Key words: Taxonomy, Morphology, Jamari River, South America, Myliobatiformes

\section{Introduction}

The family Potamotrygonidae Garman, 1913 is a very intriguing component of the Neotropical fish fauna, mainly because it represents the only supraspecific group of living elasmobranchs that evolved in a freshwater environment (Thorson et al., 1983; Lovejoy, 1996; Carvalho et al. 2003, 2004). Currently comprising four genera (Carvalho \& Lovejoy, 2011), the systematics of the group is still poorly known, especially regarding the distribution, evolutionary history and biogeography of its included species (Carvalho \& Lovejoy, 2011; Silva \& Carvalho, 2011). Of the four recognized potamotrygonid genera (Paratrygon Duméril, 1865, Potamotrygon Garman, 1877, Plesiotrygon Rosa, Castello \& Thorson, 1987, and Heliotrygon Carvalho \& Lovejoy, 2011), the genus Potamotrygon is the most diverse, with approximately 25 valid species (Carvalho et al., 2003; Rosa et al., 2008; Carvalho \& Lovejoy, 2011; Carvalho et al., 2011; Silva \& Carvalho, 2011).

The present paper describes a new species of potamotrygonid from the upper Madeira River basin, Brazil, and compares it with congeners, especially those occurring in the greater Amazon basin. This new species was initially discovered during a systematic revision of Potamotrygon scobina Garman, 1913 and allied forms (Fontenelle, 2013), based primarily on the extensive potamotrygonid material deposited in the Museu de Zoologia da Universidade de São Paulo (São Paulo). The new species, described here as Potamotrygon limai, sp. nov., is distinguished by its dorsal (especially lumbar) and tail-base color pattern, as well as dermal denticle morphology, number and arrangement of caudal spines, number of teeth, and caudal proportions, among other features. This new species further demonstrates the great variation in coloration present in the family, a fact that reinforces the need for comprehensive revisions as a sound base for describing new potamotrygonid species. 


\section{Comparative material examined}

(See also material listed in Silva, 2010; Silva \& Carvalho, 2011; Fontenelle, 2013).

Potamotrygon scobina: (holotype) MCZ 602-S (juvenile male, $238 \mathrm{~mm} \mathrm{DW}$ ), Tocantins River, Cametá, state of Pará, Brazil; MZUSP 104247 (adult male, 503 mm DW), Tocantins River, Colares, Baia de Marajó, state of Pará, Brazil, 055'34.68'S, 48¹7'25.44”'W; MZUSP 104245 (adult male, $543 \mathrm{~mm}$ DW), same data as MZUSP 104247; MZUSP 104244 (adult male, $378 \mathrm{~mm}$ DW), same data as MZUSP 104247; MZUSP 104243 (adult female, $459 \mathrm{~mm}$ DW), same data as MZUSP 104247; MZUSP 104258 (adult female, $405 \mathrm{~mm}$ DW), same data as MZUSP 104247; 104259 (?female, $298 \mathrm{~mm}$ DW), same data as MZUSP 104247; 104266 (adult male, $392 \mathrm{~mm} \mathrm{DW}$ ), same data as MZUSP 104247; 104268 (adult female, $396 \mathrm{~mm}$ DW), same data as MZUSP 104247; INPA 1774 (adult male, 330 mm DW), Uatumã River (Balbina reservoir), Presidente Figueiredo, state of Amazonas, Brazil; INPA 9096 (juvenile male, $298 \mathrm{~mm}$ DW), Solimões River, Janauacá, state of Amazonas, Brazil, 3¹7'41.57'S, 60²0’31.34”'W; INPA 9104 (adult male, $547 \mathrm{~mm}$ DW), same data as INPA 9096; INPA 15113 (juvenile male, 183 mm DW), Solimões River, state of Amazonas, Brazil.

Potamotrygon motoro: MZUSP (uncat.) PU04 (adult male, $310 \mathrm{~mm}$ DW), Madre de Díos River, municipal district of Boca Manu, state of Madre de Dios, Peru, 12³6'38"S, 71¹3'58W"; MZUSP 14771 (juvenile male, 107 mm DW), Ucayali River, municipal district of Coronel Portilio, near Ucayali, Peru.

Potamotrygon tatianae: MZUSP 107673 (adult male, $348 \mathrm{~mm}$ DW), Madre de Díos River, municipal district

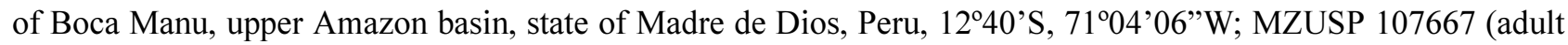
male, $362 \mathrm{~mm}$ DW), same data as MZUSP 107673; MZUSP 107668 (?preadult female, $265 \mathrm{~mm}$ DW), same data as MZUSP 107673; MZUSP 107669 (adult male, $293 \mathrm{~mm}$ DW), same data as MZUSP 107673; MZUSP 107670 (adult male, $300 \mathrm{~mm}$ DW), same data as MZUSP 107673; 107671 (adult male, $351 \mathrm{~mm} \mathrm{DW),} \mathrm{same} \mathrm{data} \mathrm{as}$ MZUSP 107673; MZUSP 107672 (?preadult male, $291 \mathrm{~mm}$ DW), same data as MZUSP 107673.

Potamotrygon orbignyi: MZUSP 104438 (juvenile male, $171 \mathrm{~mm} \mathrm{DW),} \mathrm{Xingu} \mathrm{River,} \mathrm{municipal} \mathrm{district} \mathrm{of} \mathrm{São}$ Félix do Xingú, state of Pará, Brazil (06³9’36”S, 5200’W); MZUSP 103897 (adult male, 335 mm DW), Tapajós River, municipal district of Santarém, state of Pará, Brazil (02 $2^{\circ} 6^{\prime} 48^{\prime \prime} \mathrm{S}, 55^{\circ} 00^{\prime} \mathrm{W}$ ); MZUSP 104972 (juvenile female, $165 \mathrm{~mm}$ DW), Negro River, municipal district of Barcelos, state of Amazonas, Brazil $\left(00^{\circ} 58^{\prime} 48^{\prime \prime} \mathrm{S}\right.$, $\left.62^{\circ} 55^{\prime} 12^{\prime \prime} \mathrm{W}\right)$.

\section{Acknowledgements}

Maíra Ragno, Thiago Loboda, Diego Vaz, Mateus Soares, Leandro Yokota, Murilo Carvalho, and Carolina Laurini, from the Laboratório de Ictiologia da Universidade de São Paulo are thanked for their assistance during the development of this study and for valuable comments regarding this project. José Lima de Figueiredo and Michel Gianeti, from the Museu de Zoologia da Universidade de São Paulo (MZUSP) are especially thanked for their help and support during the many visits to the fish collection. Fernando P. L. Marques (Departamento de Zoologia, IB/ USP) is sincerely thanked for providing stingray specimens crucial for this study, including all material of the new species. Enio Mattos and Philip Lenktaitis (Departamento de Zoologia, IB/USP) are thanked for their help during SEM sessions. Reginaldo Silva, Hugo Idalfo, Silvana Unruh and Stefano Hagen (Faculdade de Medicina Veterinária e Zootecnia, USP) are thanked for radiographing specimens used in this study. This study was funded by the Fundação de Amparo à Pesquisa do Estado de São Paulo (FAPESP) through grants to the first (2011/039527), second (2010/52677-6), and third (2002/06459-0, 2010/51193-5, 2012/02349-8, 2012/09877-0, 2012/05391-5) authors, and by the Conselho Nacional de Desenvolvimento Científico e Tecnológico (CNPq) to the first (135313/ 2011-2) and third (304615/2011-0) authors.

\section{References}

Carvalho, M.R. de \& Lovejoy, N.R. (2011) Morphology and phylogenetic relationships of a remarkable new genus and two new species of Neotropical freshwater stingrays from the Amazon basin (Chondrichthyes: Potamotrygonidae). Zootaxa, 2776, 13-48.

Carvalho, M.R. de, Lovejoy, N.R. \& Rosa, R.S. (2003) Family Potamotrygonidae. In: Reis, R.E, Feraris, C.J. \& Kullander, S.O. (Eds.), Checklist of the Freshwater Fishes of South and Central America. Porto Alegre, Edipucrs, pp. 22-29. 
Carvalho, M.R. de, Maisey, J.G. \& Grande, L. (2004) Freshwater stingrays of the Green River Formation of Wyoming (Early Eocene), with the description of a new genus and species and an analysis of its phylogenetic relationships (Chondrichthyes: Myliobatiformes). Bulletin of the American Museum of Natural History, 284, 1-136. http://dx.doi.org/10.1206/0003-0090(2004)284<0001:fsotgr >2.0.co;2

Carvalho, M.R. de \& Ragno, M.P. (2011) An unusual, dwarf new species of Neotropical freshwater stingray, Plesiotrygon nana, sp. nov., from the upper and mid Amazon basin: the second species of Plesiotrygon (Chondrichthyes: Potamotrygonidae). Papéis Avulsos de Zoologia, 51 (7), 101-138.

Carvalho, M.R. de, Sabaj Perez, M.H. \& Lovejoy, N.R. (2011) Potamotrygon tigrina, a new species of freshwater stingray from the upper Amazon basin, closely related to Potamotrygon schroederi Fernandez-Yépez, 1958 (Chondrichthyes: Potamotrygonidae). Zootaxa, 2827, 1-30.

Chu, Y.T. \& Wen, C.M. (1979) A study of the lateral-line canals system and that of Lorenzini ampullae and tubules of Elasmobranchiate fishes of China. In: Monograph of Fishes of China. 2. Shangai, People's Republic of China, Shangai Science and Technology Press, pp. 117-132, 64 pls.

Compagno, L.J.V. (1973) Interrelationships of living elasmobranchs. In: Greenwood, P.H., Patterson, C. \& Miles, R.S. (Eds.), Interrelationships of fishes. Zoological Journal of the Linnean Society, 53, 15-61.

Compagno, L.J.V. \& Roberts, T.R. (1982) Freshwater stingrays (Dasyatidae) of southeast Asia and New Guinea, with descriptions of a new species of Himantura and reports of unidentified species. Environmental Biology of Fishes, 7 (4), 321-339.

Deynat, P. \& Séret, B. (1996) Le revêntement cutané des raies (Chondrichthyes, Elasmobranchii, Batoidea). I - Morphologie et arrangement des denticules cutanés. Annales des Sciences Naturelles, Zoologie, 17 (2), 65-83. http://dx.doi.org/10.1007/bf00005567

Ewart, J.C. \& Mitchell, H.C. (1892) On the lateral sense organs of elasmobranchs. II. The sensory canals of the common skate (Raja batis). Transactions of the Royal Society of Edinburgh, 37, 87-105.

Fontenelle, J.P. (2013) Revisão taxonômica do complexo Potamotrygon scobina Garman, 1913 (Chondrichthyes: Myliobatiformes: Potamotrygonidae), com inferências biogeográficas. Unpublished Master's Dissertation, Universidade de São Paulo, São Paulo, 225 pp.

Garman, S. (1888) On the lateral canal system of the Selachia and Holocephala. Bulletin of the Museum of Comparative Zoology, 17, 57-119.

Loboda, T.S. \& Carvalho, M.R. de (2013) Systematic revision of the Potamotrygon motoro (Müller \& Henle, 1841) species complex in the Paraná-Paraguay basin, with description of two new ocellated species (Chondrichthyes: Myliobatiformes: Potamotrygonidae). Neotropical Ichthyology, 11 (4), 693-737.

Lovejoy, N.R. (1996) Systematics of myliobatoid elasmobranchs: with enphasis on the phylogeny and historical biogeography of neotropical freshwater stingrays (Potamotrygonidae: Rajiformes). Zoological Journal of the Linnean Society, 117 (2), 207-257. http://dx.doi.org/10.1111/j.1096-3642.1996.tb02189.x

Nishida, K. (1990) Phylogeny of the suborder Myliobatidoidei. Memoirs of the Faculty of Fisheries Hokkaido University, 37 (1/2), 1-108.

Rosa, R.S. (1985) A systematic revision of the South American freshwater stingrays (Chondricthyes: Potamotrygonidae). Unpublished PhD Thesis, College of William and Mary, Williamsburg, $523 \mathrm{pp}$.

Rosa, R.S., Carvalho, M.R. de \& Wanderley, C.A. (2008) Potamotrygon boesemani (Chondrichthyes: Myliobatiformes: Potamotrygonidae), a new species of Neotropical freshwater stingray from Surinam. Neotropical Ichthyology, 6 (1), 1-8.

Silva, J.P.C.B. da (2010) Revisão taxonômica e morfológica do complexo Potamotrygon orbignyi (Castelnau, 1855) (Chondrichthyes: Myliobatiformes: Potamotrygonidae). Unpublished Master's Dissertation, Universidade de São Paulo, São Paulo, 191 pp. http://dx.doi.org/10.1590/s1679-62252011000100021

Silva, J.P.C.B. da \& Carvalho, M.R. de (2011) A taxonomic and morphological redescription of Potamotrygon falkneri Castex \& Maciel, 1963 (Chondrichthyes: Myliobatiformes: Potamotrygonidae). Neotropical Ichthyology, 9 (1), $209-232$.

Taniuchi, T. \& Ishihara, H. (1990) Anatomical comparison of claspers of freshwater stingrays (Dasyatidae and Potamotrygonidae). Japanese Journal of Ichthyology, 37 (1), 10-16.

Thorson, T.B., Brooks, D.R. \& Mayes, M.A. (1983) The evolution of freshwater adaptation in stingrays. National Geographic Society Research Reports, 15, 663-694. 